\title{
PENGARUH PENGETAHUAN DAN MASA BEKERJA BIDAN \\ TERHADAP PELAKSANAAN UNIVERSAL PRECAUTION PADA \\ PERTOLONGAN PERSALINAN DI WILAYAH KOTA \\ TANGERANG SELATAN
}

\author{
Tutik Iswanti ${ }^{1}$, R. Detty Siti Nurdiati ${ }^{2}$, Herlin Fitriana K. ${ }^{3}$ \\ ${ }^{1}$ Jurusan Kebidanan Poltekkes Kemenkes Banten \\ ${ }^{2}$ Fakultas Kedokteran Universitas Gajah Mada \\ ${ }^{3}$ Universitas Aisyiyah Yogyakarta
}

\begin{abstract}
ABSTRAK
Universal precaution merupakan bagian dari keselamatan dan kesehatan kerja (K3) yang sangat diperlukan dalam aktivitas pelayanan kesehatan dan secara signifikan mengurangi jumlah insiden kerja karena paparan darah. Dikota Tangerang selatan pada tahun 2015 terdapat 15 kasus kematian ibu, penyebab infeksi intrapartum $(6,7 \%)$ dan kematian bayi sebanyak 37 kasus, penyebab dari infeksi sebesar 13,5\% dan 10,8\% karena HIV/AIDS. Penelitian ini bertujuan untuk mengetahui hubungan pengetahuan dan masa bekerja terhadap pelaksanaan universal precaution pada pertolongan persalinan oleh bidan. Pada penelitian ini terdapat variabel independent yaitu pengetahuan dan masa bekerja dan variabel dependent yaitu pelaksanaan universal precaution pada pertolongan persalinan. Desain penelitian yang digunakan adalah Cross Sectional, berupa pengisian kuesioner dengan sampel 88 bidan. Uji statistik yang digunakan adalah Uji Fisher. Hasil penelitian yang didapat adalah bidan yang mempunyai pengetahuan baik sebanyak $89,9 \%$, masa bekerja lama sebanyak $89,8 \%$ dan melaksanakan universal precaution pada pertolongan persalinan dengan baik sebanyak $84,1 \%$. Terdapat hubungan yang signifikan antara pengetahuan terhadap pelaksanaan universal precaution dengan pvalue 0,033 dan terdapat hubungan yang bermakna antara masa bekerja terhadap pelaksanaan universal precaution dengan pvalue 0,004 .
\end{abstract}

Kata Kunci: Pengetahuan Universal precaution, Masa Bekerja Bidan, Persalinan

Korespondensi: Tutik Iswanti, E-mail: tutik8375@gmail.com

\section{PENDAHULUAN}

Universal precaution merupakan bagian dari keselamatan dan kesehatan kerja (K3) yang sangat diperlukan dalam aktivitas pelayanan kesehatan. Penggunaan universal precaution secara signifikan mengurangi jumlah insiden kerja karena paparan darah (Fayaz et al, 2014). Pengetahuan membuat seseorang mulai mengenal dan mencoba atau melakukan suatu tindakan. Penambahan pengetahuan tidak bisa dilakukan dalam waktu singkat tetapi dilakukan secara terus menerus dan berkelanjutan. 
Pemberian informasi baru juga sangat penting sehingga dapat menambah dan memperdalam pengetahuan, sehingga dengan demikian pengetahuan tetap menjadi kontrol terhadap seseorang untuk berperilaku baik (Green, 1980).

Berdasarkan penelitian Agu, et al (2014), menyatakan bahwa petugas kesehatan yang mempunyai pengetahuan baik $18 \%$, sikap positif $88,3 \%$ dan menerapkan universal precaution 19,7\%. Bidan memiliki pengetahuan yang kurang mengengai prosedur pelaporan insiden yang dapat membahayakan kehidupannya (Donker et al, 2014). Kepatuhan bidan dalam pencegahan infeksi pada pertolongan persalinan sebanyak 42,9\% (Mardinanti, 2013).

Menurut Fayaz, et al (2014) terdapat hubungan antara lama bekerja dengan pelaksanaan universal precaution. Sesorang yang telah lama bekerja $(\geq 7$ tahun) akan lebih konsisten dalam melaksanakan universal precaution. Hal ini tidak sejalan dengan penelitian Eka (2012), yang menyatakan bahwa tidak ada hubungan antara lama bekerja dengan perilaku penerapan kewaspadaan universal.

Penyebab kematian ibu di Indonesia pada tahun 2014 karena infeksi sebanyak 7,3\% (Kemenkes RI, 2014). Provinsi
Banten termasuk dalam enam Provinsi yang menyumbangkan AKI dan AKB terbesar pada tahun 2012. Dimana 52,6\% kematian berasal dari enam Provinsi termasuk Provinsi Banten (SDKI, 2012). Dikota Tangerang selatan pada tahun 2015 terdapat 15 kasus kematian ibu, salah satu penyebab kematian ibu adalah infeksi intrapartum (6,7\%). Selain kematian ibu, terdapat juga kematian bayi sebanyak 37 kasus, penyebab dari infeksi sebesar 13,5\% dan 10,8\% karena HIV/AIDS (Dinas Kesehatan Kota Tangerang Selatan, 2016).

Masyarakat menganggap sarana kesehatan merupakan tempat pemeliharaan kesehatan. Pasien mempercayakan sepenuhnya kesehatan dirinya atau keluarganya kepada petugas kesehatan, maka kewajiban petugas kesehatan adalah menjaga kepercayaan tersebut. Pelaksanaan kewaspadaan universal merupakan langkah penting untuk menjaga sarana kesehatan (Rumah sakit, puskesmas dll) sebagai tempat penyembuhan, bukan menjadi sumber infeksi (Depkes RI, 2010).

Kepmen No. 496/Menkes/SK/IV/2005 tentang Pedoman audit di Rumah Sakit, yang bertujuan mencapai pelayanan medis prima yang jauh dari kejadian medical error dan meningkatkan 
keselamatan pasien. Dalam Organisasi profesi Ikatan Bidan Indonesia (IBI), standar pertolongan persalinan terdapat pada standar 9, 10, 11 dan 12 termasuk salah satu didalamnya adalah pencegahan infeksi (JNPK-KR, 2012).

Berdasarkan data-data tersebut diatas, maka penulis tertarik untuk melakukan penelitian tentang "Pengaruh Pengetahuan dan Masa Bekerja Bidan Terhadap Pelaksanaan Universal Precaution Pada Pertolongan Persalinan Di Wilayah Kota Tangerang Selatan".

Tujuan dari penelitian ini yaitu untuk mengetahui hubungan pengetahuan dan masa bekerja terhadap pelaksanaan universal precaution pada pertolongan persalinan oleh bidan di wilayah kota Tangerang Selatan tahun 2016

\section{METODE PENELITIAN}

Penelitian ini dilakukan dengan rancangan cross sectional. Penggunaan rancangan cross sectional karena melakukan pengukuran terhadap beberapa variabel serta melakukan pengukuran hubungan antara variabelvariabel tersebut dalam satu kondisi yang realistik. Populasi dalam penelitian ini yaitu seluruh bidan praktik mandiri di wilayah Kota Tangerang Selatan yaitu sebanyak 88 bidan. Teknik pengambilan sampel yang digunakan adalah Total sampling. Hal ini dimaksudkan agar didapatkan data yang lebih objektif dari seluruh responden. Analisa data yang digunakan adalah univariat dan bivariat.

\section{HASIL PENELITIAN}

1. Analisis univariat

a. Karakteristik Responden

Tabel 1.1 Distribusi frekuensi karakteristik responden

No Karakteristik Frekuensi Presentase (\%)

\begin{tabular}{|c|c|c|c|}
\hline \multicolumn{4}{|c|}{ 1. Umur } \\
\hline & $<35$ tahun & 36 & 40,9 \\
\hline & $\geq 35$ tahun & 52 & 59,1 \\
\hline & Jumlah & 88 & 100 \\
\hline \multirow[t]{5}{*}{2.} & Pendidikan & & \\
\hline & DIII Kebidanan & 26 & 29,6 \\
\hline & DIV Kebidanan & 47 & 53,4 \\
\hline & S2 Kesehatan & 15 & 17,0 \\
\hline & Jumlah & 88 & 100 \\
\hline
\end{tabular}

Berdasarkan tabel 1.1 menunjukkan bahwa dari 88 responden sebagian besar $(59,1 \%)$ berumur $\geq 35$ tahun dan $40,9 \%$ berumur $<35$ tahun. Sebagian besar responden $(53,4 \%)$ dengan pendidikan DIV kebidanan dan $29,6 \%$ responden dengan pendidikan DIII kebidanan serta $17 \%$ responden dengan pendidikan S2 kesehatan. 
b. Distribusi frekuensi

Tabel 1.2 Distribusi frekuensi

\begin{tabular}{llcc}
\hline No & Variabel & Frekuensi & $\begin{array}{l}\text { Presentase } \\
(\%)\end{array}$ \\
& & & \\
\hline 1. & Pengetahuan & & 89,8 \\
& Baik & 79 & 10,2 \\
& Kurang & 9 & \\
2. & Masa & & 89,8 \\
& Bekerja & 79 & 10,2 \\
& Lama & 9 & \\
& Kurang & & \\
& Lama & & \\
3. Pelaksanaan & & \\
& universal & & \\
& precaution & 74 & \\
Baik & 14 & \\
& Kurang & & \\
\hline
\end{tabular}

Berdasarkan tabel distribusi frekuensi diatas menunjukan bahwa Bidan yang melaksanakan universal precaution pada pertolongan persalinan di wilayah kota Tangerang Selatan dengan baik sebesar $84,1 \%$, mayoritas bidan dengan pengetahuan baik yaitu sebesar $89,8 \%$ dan masa kerja lama yaitu sebesar $89,8 \%$.

\section{c. Analisa Bivariat}

Tabel 2.1 Hubungan pengetahuan dan masa bekerja terhadap pelaksanaan universal precaution pada pertolongan persalinan oleh Bidan Praktik Mandiri di wilayah Kota Tangerang Selatan

\begin{tabular}{|c|c|c|c|c|c|c|c|}
\hline \multirow[t]{3}{*}{$\begin{array}{l}\text { Variabel } \\
\text { penelitian }\end{array}$} & \multicolumn{4}{|c|}{$\begin{array}{c}\text { Pelaksanaan universal } \\
\text { precaution }\end{array}$} & \multirow[t]{3}{*}{ Pvalue } & \multirow[t]{3}{*}{$\mathrm{Cl}(95 \%)$} & \multirow[t]{3}{*}{ OR } \\
\hline & \multirow{2}{*}{$\begin{array}{c}\text { Baik } \\
\mathrm{n}\end{array}$} & \multicolumn{3}{|c|}{ Kurang } & & & \\
\hline & & $\%$ & $\mathrm{n}$ & $\%$ & & & \\
\hline \multicolumn{8}{|l|}{ Pengetahuan } \\
\hline Baik & 69 & 87,3 & 10 & 12,7 & 0,033 & $1,266-24,070$ & 5,520 \\
\hline Kurang & 5 & 55,6 & 4 & 44,4 & & & \\
\hline \multicolumn{8}{|l|}{ Masa Bekerja } \\
\hline Lama & 70 & 88,6 & 9 & 11,4 & 0,004 & $2,198-42,998$ & 9,722 \\
\hline Kurang Lama & 4 & 44,4 & 5 & 55,6 & & & \\
\hline
\end{tabular}

Keterangan: n:jumlah sampel; $\%:$ jumlah sampel dalam persen; $p$ value $<0,05 ; \quad$ CI:Confidence interval; OR:Ods Ratio

Berdasarkan hasil analisis bivariat pada tabel 2.1 menunjukan bahwa hubungan pengetahuan responden terhadap pelaksanaan universal precaution pada pertolongan persalinan menunjukkan bahwa responden dengan pengetahuan baik memiliki perilaku baik 87,3\% lebih banyak dibanding perilaku kurang, tetapi responden dengan pengetahuan kurang tetap memiliki perilaku baik 55,6\% lebih banyak dibandingkan dengan perilaku yang kurang.

Hubungan antara pengetahuan dengan pelaksanaan universal precaution pada pertolongan persalinan oleh bidan praktik mandiri di wilayah kota Tangerang Selatan terdapat hubungan yang bermakna (Pvalue $=0,033$; $\mathrm{CI}=1,266-24,070 ; \mathrm{OR}=5,520)$. OR antar 
variabel sebesar 5,52 sehingga dapat disimpulkan bahwa bidan yang mempunyai pengetahuan baik 5,52 kali melaksanakan universal precaution daripada bidan dengan pengetahuan kurang.

Tabel 2.1 menunjukan bahwa hubungan masa bekerja responden terhadap pelaksanaan universal precaution pada pertolongan persalinan menunjukkan bahwa responden dengan masa bekerja lama memiliki perilaku baik 88,8\% lebih banyak dibanding perilaku kurang, tetapi responden dengan masa bekerja kurang lama memiliki perilaku baik 44,4\% lebih sedikit dibandingkan dengan perilaku yang kurang.

Hubungan antara masa bekerja dengan pelaksanaan universal precaution pada pertolongan persalinan oleh bidan praktik mandiri di wilayah kota tangerang selatan terdapat hubungan yang bermakna ( $p$ value $=0,004$; $\mathrm{CI}=2,198-42,998 ; \mathrm{OR}=9,722)$.

\section{PEMBAHASAN}

Pengetahuan dapat diperoleh melalui pendidikan formal maupun nonformal. Bermaknanya hubungan variabel pengetahuan dengan perilaku pada penelitian ini dikarenakan semua bidan yang diteliti memiliki latar belakang pendidikan formal D3 (diploma)
Kebidanan. Kewaspadaan standar untuk pencegahan infeksi pada pertolongan persalinan sudah diajarkan sehingga diasumsikan bidan-bidan sudah memiliki dasar pengetahuan tentang hal tersebut. Para bidan juga sudah mendapatkan informasi mengenai pencegahan infeksi pada pertolongan persalinan dari pendidikan nonformal melalui pelatihanpelatihan, seminar atau sosialisasi kewaspadaan standar yang sering dilakukan secara berkala di Kota Tangerang Selatan.

Pemberian informasi melalui pendidikan, pelatihan atau seminar tersebut dapat meningkatkan pengetahuan seseorang dan selanjutnya akan menimbulkan kesadaran untuk berperilaku sesuai dengan pengetahuan yang dimilikinya. Tanpa pengetahuan, seseorang tidak mempunyai dasar untuk mengambil keputusan dan menentukan tindakan terhadap masalah yang dihadapi.

Hasil penelitian ini memperkuat teori Green yang menyatakan bahwa tingkat pengetahuan merupakan faktor predisposisi dalam membentuk perilaku yang positif. Dengan pengetahuan seseorang akan mengenal dan mencoba atau melakukan suatu tindakan. Penambahan pengetahuan tidak bisa dilakukan dalam waktu singkat tetapi 
dilakukan secara terus menerus dan berkelanjutan. Pemberian informasi baru juga sangat penting sehingga dapat menambah dan memperdalam pengetahuan. Dengan demikian pengetahuan tetap akan menjadi kontrol terhadap seseorang untuk berperilaku baik.

Hasil penelitian ini sejalan dengan penelitian K. Vaz (2011) yang menyebutkan bahwa ada hubungan yang signifikan antara pengetahuan dengan kepatuhan pelaksanaan kewaspadaan universal $\quad($ Pvalue $=0,000) . \quad$ Tenaga kesehatan yang mempunyai pengetahuan yang lebih tinggi cenderung berpeluang lebih besar dalam penerapan kewaspadaan universal dan sejalan dengan penelitian Eka (2012) yang menyatakan bahwa ada hubungan yang signifikan antara pengetahuan dengan perilaku penerapan kewaspadaan universal pada pertolongan persalinan (Pvalue=0,000 dan OR=20,40). Bidan yang mempunyai pengetahuan baik kemungkinan akan menerapkan kewaspadaan universal dengan baik 20,40 kali lebih besar dibandingkan dengan pengetahuan bidan yang kurang terhadap penerapan kewaspadaan universal.
Hasil penelitian ini sesuai dengan teori yang di sampaikan oleh Notoatmodjo (2009) yang menyebutkan bahwa perilaku yang didasari pengetahuan umumnya bersifat langgeng dibandingkan perilaku yang tidak didasari oleh pengetahuan. Pengetahuan dapat membentuk keyakinan tertentu sehingga seseorang dapat berperilaku sesuai keyakinan tersebut, termasuk perilaku pelaksanaan universal precaution pada pertolongan persalinan dalam penelitian ini.

Hasil penelitian ini tidak sejalan dengan penelitian Fitri (2012) yang dilakukan di kabupaten Lampung Timur yang menyatakan bahwa tidak ada hubungan yang signifikan antara pengetahuan dengan pencegahan infeksi pada pertolongan persalinan $(\mathrm{P} v a l u e=0,568)$.

Pengalaman kerja adalah latar belakang yang menentukan secara tidak tidak langsung kinerja dan perilaku personel. Lamanya masa kerja dan pengalaman dalam mengelola kasus akan berhubungan dan berpengaruh terhadap keterampilan seseorang (Green, 1980).

Hasil analisis bivariat menunjukan bahwa antara masa bekerja dengan pelaksanaan universal precaution pada pertolongan persalinan oleh bidan praktik mandiri di wilayah kota 
Tangerang Selatan terdapat hubungan yang bermakna ( $p$ value $=0,004$; $\mathrm{CI}=2,198-42,998 ; \mathrm{OR}=9,722)$.

Pengalaman belajar dalam bekerja yang dikembangkan memberikan pengetahuan dan keterampilan yang profesional serta pengalaman belajar selama bekerja akan dapat mengembangkan kemampuan mengambil keputusan yang merupakan manifestasi dari keterpaduan menalar secara ilmiah dan etik yang bertolak dari masalah nyata dalam bidang kebidanan. Semakin lama seorang berkarya dalam organisasi maka semakin tinggi pula produktivitasnya. Juga dijelaskan bahwa ada dua perbedaan antara tenaga kerja yang masih baru dengan tenaga kerja yang masa kerjanya lama atau berpengalaman dalam tindakan. Makin lama masa kerja seseorang maka semakin bepengalaman dalam tindakan (Ariyani, 2011).

Pegalaman bekerja dapat mendukung keterampilan dan kompetensi bidan sehingga dapat memberikan pelayanan yang berkualitas. Untuk mendukung pelayanan yang berkualitas maka sesuai dengan Undang - Undang Nomor 36/2014 tentang Tenaga Kesehatan Bab VI tentang Registrasi dan Perizinan Tenaga Kesehatan dan berdasarkan hasil Kongres IBI ke XV tanggal 10-16
November 2013 di Jakarta, Pengurus Pusat IBI membuat suatu kebijakan untuk Resertifikasi dilakukan melalui penilaian portopolio, yaitu selama 5 (lima) tahun wajib mendapatkan sejumlah 25 (dua puluh lima) kredit profesi, 2 (dua) kredit profesi diantaranya diperoleh melalui Midwifery Update (MU) yang diselenggarakan oleh organisasi profesi. Bidan di Kota Tangerang Selatan sudah mengikuti pelatihan tersebut.

Hasil penelitian ini sesuai dengan teori Green (1980) yang menyatakan bahwa pengalaman kerja adalah latar belakang yang menentukan secara tidak langsung kinerja dan perilaku personel. Lamanya masa kerja dan pengalaman dalam mengelola kasus akan berhubungan dan berpengaruh terhadap keterampilan seseorang.

Hasil penelitian ini sesuai dengan penelitian Fayaz (2014) yang menyebutkan bahwa ada hubungan yang signifikan antara masa bekerja dengan praktik universal precaution. Semakin lama seseorang bekerja maka semakin banyak pengalaman dan semakin tinggi pengetahuan dan keterampilannya serta semakin konsisten dalam pelaksanaan universal precaution. 
Hasil penelitian ini sesuai dengan penelitian Ariyani (2011) yang menyebutkan bahwa terdapat hubungan yang signifikan antara lama bekerja dengan penerapan kewaspadaan universal oleh bidan praktik swasta di wilayah kota Denpasar (Pvalue=0,007).

Hasil penelitian ini tidak sejalan dengan penelitian Eka (2012) yang menyatakan bahwa tidak ada hubungan yang bermakna antara masa kerja dengan perilaku penerapan kewaspadaan universal pada pertolongan persalinan (Pvalue=1,000).

\section{KESIMPULAN}

1. Terdapat hubungan yang signifikan antara pengetahuan terhadap pelaksanaan universal precaution pada pertolongan persalinan oleh bidan praktik mandiri di wilayah Kota Tangerang Selatan.

2. Terdapat hubungan yang bermakna antara masa bekerja terhadap pelaksanaan universal precaution pada pertolongan persalinan oleh bidan praktik mandiri di wilayah Kota Tangerang Selatan.

\section{DAFTAR PUSTAKA}

Agu, P.U. Ogboy, S.J. Ezugwu, E.C. Okeke, T.C. Aniebue, P.N. (2015).
The Knowledge, Attitude, And Practice Of Universal Precaution Among Rural Primary Health Care Workers In Enugu Southeast Nigeria. World Journal of pharmacy and pharmaceutical sciences Vol. 4 Issue 09, 109-125.

Ariyani, N.W. Suindr, N.N. Sri, E.N.L.P. (2011). Faktor-Faktor Yang Mempengaruhi Penerapan Kewaspadaan Universal Bidan Praktik Swasta (BPS) Di Wilayah Kota Denpasar. Jurnal skala husada volume 8 nomor 2 september 2011: 132-137.

Depkes RI. (2010). Pedoman Pelaksanaan Kewaspadaan Universal Di Pelayanan Kebidanan. Jakarta: Depkes RI.

Dinas Kesehatan provinsi Banten. (2013). Profil Kesehatan Provinsi Banten Tahun 2012. Banten

Dinas Kesehatan kota Tangerang Selatan. (2016). Profil Kesehatan Kota Tangerang Selatan Tahun 2015. Tangerang Selatan.

Donkor, E.S. Affram, C.K. Yekple, C.K. (2014). Perceived Risk Of HIV Infection Among Midwives Working In The Labour Wards. Sci-Afric journal of scientific issues, research and essays vol. 2(4), PP 141-146.

Eka, Y. (2012). Faktor-Faktor Yang Berhubungan Dengan Perilaku Penerapan Kewaspadaan Universal Pada Pertolongan Persalinan Oleh Bidan Di Puskesmas Wilayah Kerja Dinas Kesehatan Kabupaten Badung Bali Tahun 2012. Skripsi. Universitas Indonesia. 
Fayaz, S.H. Michiyo, H. Tomoyo, H. Sharker, M.A.B. Zakhro, D. Nobuyuki, H. (2014). Knowledge And Practice Of Universal Precautions Among Health Care Workers In Four National Hospitals In Kabul, Afganistan. J Infect Dev Ctries 4(8): 535-542.

Fitria, W. (2012). Faktor-Faktor Yang Berhubungan Dengan Perilaku Bidan Dalam Pencegahan Infeksi Saat Melakukan Pertolongan Persalinan Di Kabupaten Lampung Timur Tahun 2012. Skripsi. Universitas Indonesia.

Green, LW., Kreuter, M.W., Deeds, S,G., \& Partridge, K.B. (1980). Health Education Planning A Diagnostic Approach. Califarnia: Mayfield Publishing Compeni.

JNPK-KR. (2012). Asuhan Persalinan Normal Asuhan Esensial Bagi Ibu Bersalin Dan Bayi Baru Lahir Serta Penatalaksanaan Komplikasi Segera Pasca Persalinan Dan Nifas. Jakarta: JNPK-KR.

Kemenkes RI. (2014). Profil Kesehatan Indonesia Tahun 2013. Jakarta: Kemenkes RI

K Vaz, D McGrowder, R Alexander, L Gordon, $\mathrm{P}$ Brown, $\mathrm{R}$ Irving. (2011). Knowledge, Awareness And Compliance With Universal Precautions Among Health Care Workers At The University Hospital Of The West Indies, Jamaica. Theijoem Vol. 1 Number 4.

Notoatmodjo. (2014). Ilmu Peilaku Kesehatan. Jakarta: Rineka Cipta
Survei Demografi dan Kesehatan Indonesia.( 2012). Rigkasan Hasil. Jakarta

Sutanto. (2010). Analisis Data Kesehatan. Fakultas Ilmu Kesehatan Universitas Indonesia. 